\title{
Miranda
}

Revue pluridisciplinaire du monde anglophone /

Multidisciplinary peer-reviewed journal on the English-

speaking world

$17 \mid 2018$

Paysages et héritages de David Bowie

\section{The Dancing Sexualized Archetype : Kelley Abbey's Reinterpretation of the Dance of the Seven Veils in Strauss's Salomé}

\section{Gerrard Carter}

\section{OpenEdition}

\section{Journals}

Electronic version

URL: http://journals.openedition.org/miranda/13851

DOI: $10.4000 /$ miranda. 13851

ISSN: 2108-6559

\section{Publisher}

Université Toulouse - Jean Jaurès

\section{Electronic reference}

Gerrard Carter, "The Dancing Sexualized Archetype : Kelley Abbey's Reinterpretation of the Dance of the Seven Veils in Strauss's Salomé", Miranda [Online], 17| 2018, Online since 01 October 2018, connection on 16 February 2021. URL: http://journals.openedition.org/miranda/13851 ; DOI: https:// doi.org/10.4000/miranda. 13851

This text was automatically generated on 16 February 2021.

\section{cc)}

Miranda is licensed under a Creative Commons Attribution-NonCommercial-NoDerivatives 4.0

International License. 
The Dancing Sexualized Archetype : Kelley Abbey's Reinterpretation of the Dance of the Seven Veils in Strauss's Salomé

Gerrard Carter

\section{Excerpt/Photographies of the show}

1 Excerpt : Dance of the Seven Veils Montage - Salome 2012. @ Opera Australia https://www.youtube.com/watch ?v =8A0qgC3mGUw

Photographies: Salome Opera Australia (2012) by courtesy of Opera Australia. Photographer : Jeff Busby 
[Fig. 1]

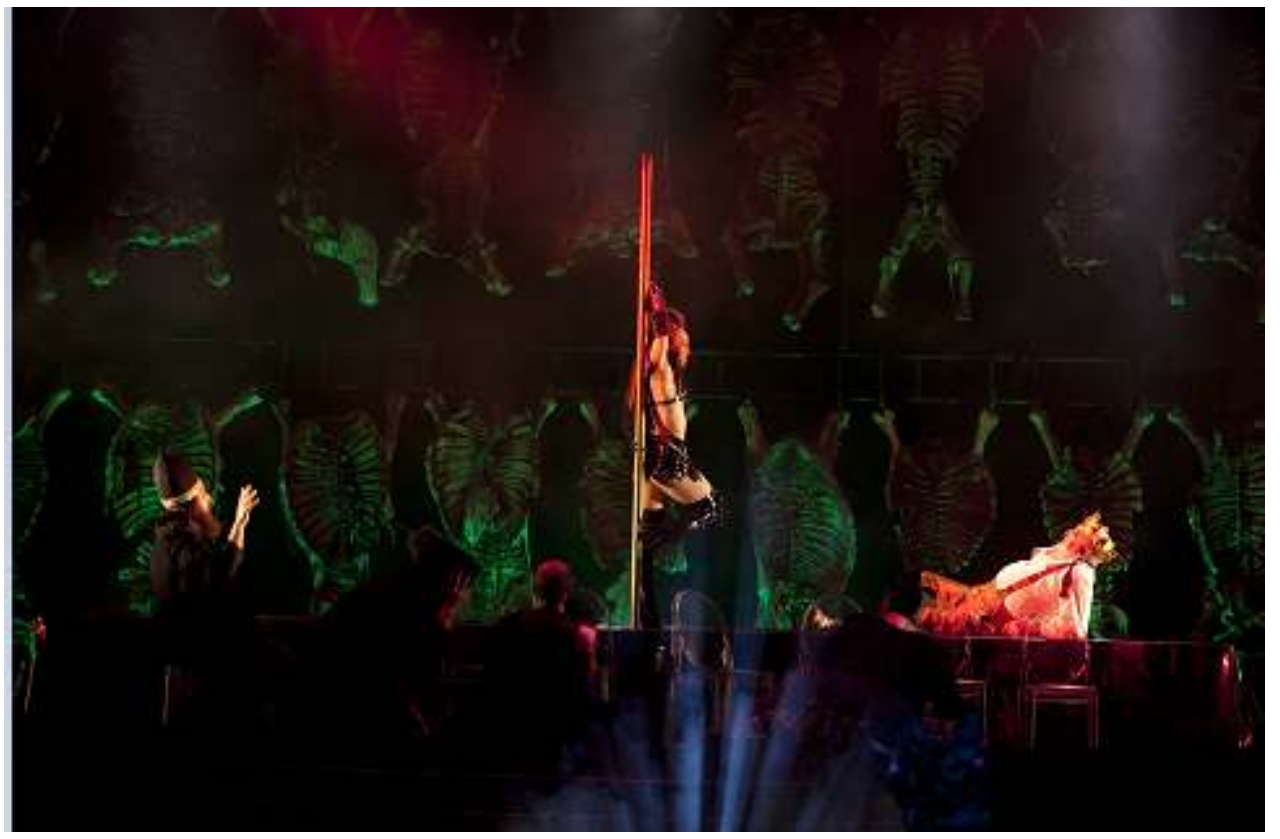

[Fig. 2]

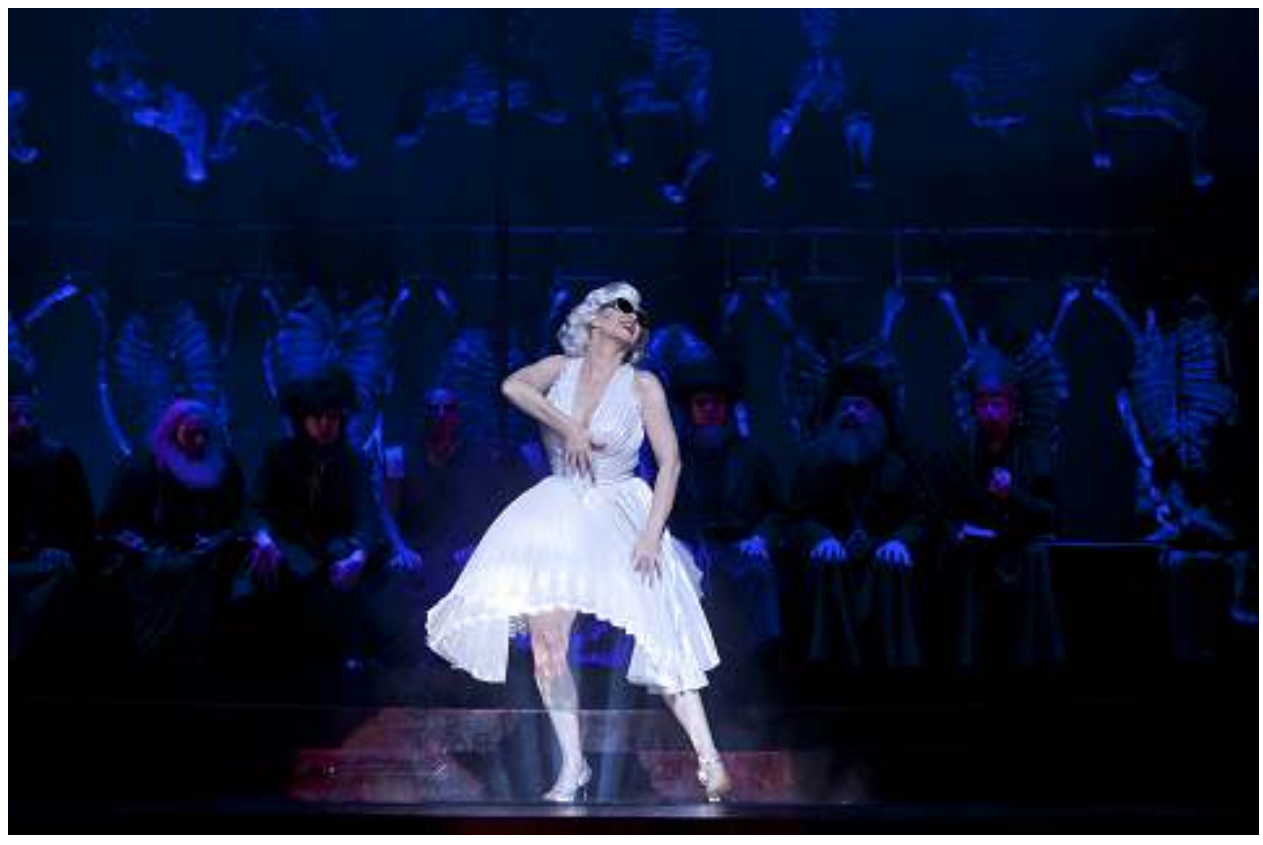


[Fig. 3]

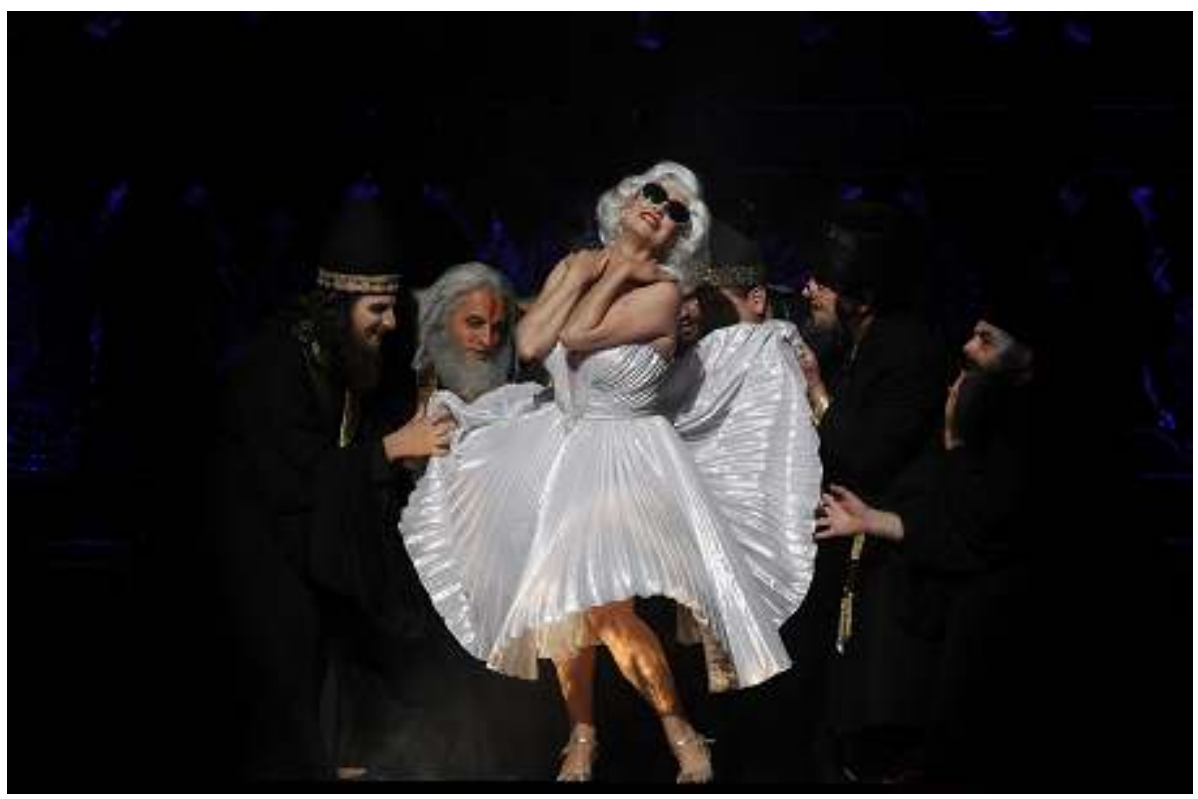

\section{Essay}

Opera Australia's 2012 controversial interpretation of Strauss's iconic opera Salomé was an abject staging dripped in blood as large shanks of meat encased the proscenium to envelop Wilde's drama with a sense of foreboding death. While the production was directed by Gale Edwards, it was choreographer Kelley Abbey's original and innovative interpretation of the Dance of the Seven Veils that was the focal point among critics and opera enthusiasts alike providing a scintillating and striking reinterpretation of Wilde's terse one line stage direction ${ }^{1}$. Peter McCallum's review for the Sydney Morning Herald October 15, 2012 entitled Fresh Twist Lifts Essay In Desire and Decadence described Abbey's new translation of the dance to be "[m]usically powerfully (sic), visually striking", and "dramatically gripping", adding that the production takes "a work that is sensational rather than truth-seeking, and inserts it garishly into contemporary mythology".

3 Never one to shy away from controversy, Abbey's interpretation of the dance included such abject themes as paedophilia, sadomasochism, religious desecration through the sexualization of religious idols and cinematic icons. Abbey decided to forego the customary yet arduous task of choreographing a nine-minute dance solo for an opera singer who possessed little or no dance training and instead placed dance at the forefront by hiring professional dancers also skilled in aerial arts. In doing so, each of the seven veils was performed by one of the employed dancers. However, Cheryl Barker who starred as Salomé performed three of the veils, which required less technically challenging choreography. Abbey returned the art of dance to Strauss's infamous opera as when the work was first created, and in the decades that followed, a ballerina was hired to execute the veiled dance (Santini 2011, 237).

4 By showcasing seven different archetypal images of the sexualized woman as seven different dancing veils, Abbey's inventive and original approach to the infamous dance challenged and remodelled preconceived notions of seduction in Western culture. 
Abbey employed the art of seduction to reinforce Salomé's personal goal of a homicidal conquest while utilising seven diverse archetypal motifs or fantasies of the sexualized woman. Salomé's seduction is dubious and ultimately fatal. In this regard, Abbey's translation of the dance re-figured the art of seduction "as a play of desires and meanings between performers and spectators. Seduction, like ambiguity, becomes an embodied practice [...] Seduction becomes ambiguous-ambiguity becomes seductive" (Claid 2006, 7) and it is while imbedded in this seduction that the spectator is prompted to produce multiple interpretative possibilities.

Abbey challenged the sensibilities of opera enthusiasts who were familiar with Strauss's nine-minute instrumental as they engaged in the re-figuration of seduction between the female dancers and Herod. Abbey's choreography of the Dance of the Seven Veils, which was described as a "parade of tawdry male fantasies" (McCallum 2012), situated the spectator alongside Herod to engage in a seduction of ambiguity. Claid explains :

The spectator's watching practice embraces ambiguity of meaning, but the performer's dancing practice is often in contrast to that of the spectator and, subsequently, the writer. In fact, it is frequently the performer's attention to the full inhabiting of the performed material that instigates the ambiguous surface of meanings. In other words, what the performer does is not what the spectator sees $(2006,7-8)$.

6 The dance in this locale therefore becomes an emblematic illustration of Umberto Eco's theory of "openness" or "open work" as it is delineated in Opera Aperta (1962). Open work compels the spectator to derive his or her unique perspective towards an interpretative analysis of the dance regardless of the dancer's original intention. The diverse exegetical conclusions that are formed become instrumental in promoting a greater degree of collaboration between the artist and the spectator. As a consequence, the fact that a dancer does not speak, write or read but instead uses his or her body as an instrument to communicate and transfer meaning to the recipient, offers a greater degree of ambiguity of translation. Through a nonverbal form of expression to interpret Wilde's terse one line stage direction, Abbey's choreography upon seven distinct veils morphed into a plethora of meanings to challenge social, cultural and political conventions. In doing so, such meanings were shrouded in a luring cloak of seductiveness and attraction.

7 To commence each solo performance, the female dancer initially appeared covered with a transparent red veil. The choice of the colour red intensified the notion of lust and death as Herod slowly and ever so carefully removed each veil. When I interviewed choreographer Kelley Abbey November 7, 2015, she described this as Herod carefully unwrapping a gift to intensify the sexual desire he felt for each veil and in this case, each sexualized woman and male erotic fantasy. Abbey wanted to demonstrate how some men perceive women sexually. She stated that "Each veil was important as it essentially offered a separate story". When one imagines the Dance of the Seven Veils, one thinks of the erotic build, the striptease, as each veil falls bringing us closer to the naked and desired Salomé. By offering a "separate story" for each veil, Abbey endeavours to present the audience with a metaphorical guide to the core point of desire, an ecstatic build of sexual tension that ultimately reaches the extreme sexual climax : an unveiled Salomé.

Shrouding each dancer in a transparent red veil brings into play the idea that the veil represents a "penetration" (Riquelme 1995, 603). In this regard, red, the colour of blood depicts the deflowering of the pubescent and virginal Salomé. The breaking of the 
hymen represents her swift transformation into womanhood. In her illuminating work, Salome and Judas in the Cave of Sex (1987), Ewa Kuryluk describes the dance as an act of "imaginary erotic intercourse" and characterizes its conclusion as the climax of the play, it's "an orgasm (a small death) for the girl who danced and the man who watched her" (222). Kuryluk's analogy sheds compelling light on the correlation between Salomé's sexual desires for the sacred prophet and the dance that represents her first sexual experience and loss of her virginity when we consider that Iokanaan is imprisoned in the same cistern as Salomé's father. Therefore, Salome cannot help but succumb to her desires when she encounters for the very first time, a male other than her father who emerges from the dark depths of his prison. For Salomé, the Dance of the Seven Veils was not simply a carnal striptease, but a dance of insatiable erotic desire and death. The climax of the dance was not only the loss of her virginity but with it came an act of murderous intent: the prophet's severed head. Through seven different dancing veils, Abbey was able to entice the audience to participate in the visual poetics of the sexualized body, which as a result offered a distinct narrative ellipse to arrive at the point of Salomé's deathly climax.

The first veil explored the perverted notion of paedophilia between an older man and a young girl. This character could be conceived as Salomé in her youngest incarnation. Dressed as a baby doll, her hair adorned in tightly wound pigtails and holding a teddy bear close to her chest, she sits upon Herod's knee as he gently caresses the inside of her thighs. Abbey described this scene as a dangerous place to venture into as Herod represented a lecherous paedophile : "The young girl thinks it's play but it is not". This was a confronting way to commence the dance as the character of the baby doll conveys the paradoxical Salomé who is initially considered to be innocent, chaste, and virginal to the extreme.

10 The lecherous way in which the sinister Herod cradles the infant Salomé in his arms, caressing the inner thighs of an underage and forbidden girl transformed into a sexual object can allude to the salacious way in which Herod invites his stepdaughter to eat and drink with him: "Salomé, come and eat fruits with me. I love to see in a fruit the mark of thy little teeth. Bite but a little of this fruit, that I may eat what is left" (102) and "Dip into it thy little red lips, that I may drain the cup" (100). Salomé's childlike features are also explored when Herod relishes the fact that Salomé will dance with naked feet, "Thy little feet will be like white doves. Thy will be like little white flowers that dance upon the trees" (138). From the very beginning of the dance the audience is thrust into a vetoed world of dangerous forbidden sex with a child who possesses "tiny teeth", "little red lips" and "little feet" placing the spectator in the thick of the uncomfortable and destabilising world of the incest and paedophilic taboo.

11 Following the young, innocent yet violated baby doll, the second veil was the quintessential French maid offering a playful sense of seductive ambiguity. A staple of male erotic fantasy and fetishism, the French maid was stereotypically dressed in a black and white uniform complete with an apron and a feather duster. Consistent with pop-culture's clichéd French sexiness, the French maid was flirty and easily sexually excited. No longer the innocent and tampered with baby doll, the second dancer used the feather duster which is often associated, in psychoanalytic terms, with a phallic symbol in an explicit and sexual way, not only as she dusted her surroundings, but also as she caressed her body. Herod looks on languidly as the submissive female is compelled to do precisely what he desires, in this case, to dance and use the duster to 
not only touch herself in a self gratifying manner but also to playfully taunt the Tetrarch. He responds to her sexual needling in a delirious manner.

The seduction of the dance was explored to the fullest extent as the second veil moved from the innocent and immobile stance of the baby doll to a solo, which required more dance technique, and more enticing sexual movements. The choreography is however brought to an abrupt end as Herod suddenly takes the French maid from behind. Not perturbed in the slightest, the French maid giggles enthusiastically engaging in an alluring game of seduction. The French maid revelled in playing the submissive role as Strauss's composition slowly advanced in tempo to coincide with the seductive build of the orchestral music.

The "removal" of the third veil took the audience from the submissive to the domineering as the element of the striptease was explored to the extreme through the use of a female pole dancer (Fig. 1). Dressed in sadomasochistic attire, the third veil initially displayed advanced acrobatic feats high atop a pole securely positioned centre stage while Herod looked on, overwhelmed with desire. Each athletic move propelled Herod's lust and hunger even further as he could merely look but was unable to touch. Although left to the reader's imagination, the Dance of the Seven Veils is essentially a dance of persuasion and desire as the young princess used her provocative feminine power to attain what she wanted. Using this theme, Abbey took full advantage of the dancer's enticing gaze. The Tetrarch's body shook in sexual impatience as the dancer descended from the pole before approaching him, her spiked boots straddling his head as she bewitchingly peered into his eyes. Domineering and lecherous, the dancer aggressively grasped the king by his neck bringing his face towards hers. She was the femme fatale par excellence and the most tyrannical of all seven veils, relinquishing her hold upon him mere moments before they locked lips, and then forcibly pushing him away.

While Abbey is once again playing with clichés of archetypal images of feminine sexuality, she uses each veil as a progression to illustrate the arc in Salomé's character. From baby doll to the submissive and sexy French maid advancing to sadomasochistic dominatrix, the third veil represented Salomé's passage into womanhood from chaste virgin to demonic whore. The dance is not only one of seduction and sex but is also the precursor to murder and death. The reward for Salomé's dance is the beheading of the holy prophet while also signifying the princess losing her virginity, as it is in fact her first sexual experience. In using familiar yet cliché motifs characterising the various ways men may sexually objectify women, Abbey astutely exhibits the transition from young innocent girl, chaste, pure, and virginal to a sexualized woman who learns rather rapidly that she can utilize her feminine sexual powers to obtain what she wants. The fact that the object of Salomé's desires is a severed head which she in turn uses to participate in one of the most abject forms of evil : necrophilia, shrouds her dance in a sinister veil of perpetual maliciousness. She is the demonic dancer, the vampiric harlot who will stop at nothing to satisfy her desires. Representing this veil as the fetishized dominatrix, Abbey presented the quintessential erotic male sexual fantasy of the domineering woman who takes absolute control while also encapsulating Salomé's transition from innocence to lewd and shameless enslaver.

Following the latex wearing sadist, the fourth veil paid homage to Hollywood cinema of the 1950s by showcasing the next dancing role as Marilyn Monroe (Fig. 2) in her most recognizable scene from the classic film The Seven Year Itch (1955). A common phrase 
signifying infidelity, the notion of "the seven year itch" refers to a spouse engaging in an extra-marital affair after around seven years of marriage. Once the initial honeymoon period has diminished and a relationship has began to decline, a spouse is said to experience a "seven year itch", a restless or anxious desire to engage in a romantic episode with someone other than his or her partner. The number seven becomes sexualized in its ambiguous semantic reference as to examine this term in relationship to Wilde's enigmatic stage direction: "Salomé dances the dance of the seven veils".

Marilyn Monroe, the quintessential screen goddess, revels in being worshipped to the point of adulation by the banquet attendees. As depicted in the film, Marilyn's white, now iconic, dress moved as an upward gust of wind from a subway grate wildly propelled the dress to invoke one of the most iconic moments in cinematic history. Abbey utilised the public's intimate relationship with recognisable idolatry to probe the fetishistic and patriarchal male gaze. However, while exploring this notion, Abbey chose to alter the trajectory of desire to embolden the dancing veil. She stated that:

The audience could perceive that I was perhaps objectifying Marilyn as a piece of meat but I was more concerned with Marilyn being manipulative and intelligent enough to make those men look at her, to make herself a prize and attractive rather than her be a victim of men.

Abbey achieved this erotic inversion by also reversing the perception of the veiled woman. Abbey chose to shroud the veil in duplicity by modifying the iconic scene as Marilyn wore large black sunglasses; her face obscured as her eyes are hidden from not only the men who eagerly gazed upon her but also from the audience. Therefore, there is an element of deception and secretiveness to the starlet, which the original cinematic treatment did not possess.

In Abbey's incarnation, Marilyn was untouchable as the Jews surrounded her, their frenzied male hands beset upon her in a desperate embrace. The Jews, who in Wilde's play are always disputing about their religion: "The Jews. They are always like that. They are disputing about their religion" (46) are now distracted, thrust in the throes of the veil's carnal self-adulation and reverie. By wearing dark sunglasses, Marilyn is turning her erotic gaze inward. She gains the power of her sight as she can gaze out at the audience but the audience is unable to peer into her eyes. In this way, the veil's (Marilyn's) gaze is internalised and thus drawing the audience into a web of intrigue and mystery. It is interesting to note that this masking is in direct opposition to the part of the body usually veiled as Marilyn displays the flesh of her upper breasts and her plunging neckline. This modern representation takes the oriental concept of the veil and reverses it.

19 When one conceptualises the veiled woman, it is her eyes that are revealed while most of her body is covered. In Abbey's interpretation of the veiled starlet, the decadence of the western woman is heightened to rival that of a preconditioned oriental fantasy. Marilyn is flirtatious, revelling in her open and free sexuality. However, at the same time she is also veiled. Her eyes are covered as she refuses to reveal the "windows to her soul". She sees out but we cannot see in. She is therefore untouchable. Controlling her sexuality in a masterful game of power play, Marilyn is the seductress who may lure our attention but who will ultimately betray us as she denies us the power of her sight. 

Virgin Mary who, initially appeared as the sacred Madonna adorned in conventional religious regalia bathed in a celestial light, suddenly strips to reveal herself as a go-go dancer dressed in salacious attire. Emboldened by a cheering crowd of onlookers, the Madonna performs familiar moves reminiscent of the 1960s go-go dancing clubs. The stage lighting swiftly changed to a disco red to coincide with the veil's abrupt reversal in character. Abbey explained: "In this respect the dancer was not just dancing for Herod but for all the men in the room". Abbey was attracted by the matriarchal figure being sexualized. While, the Madonna retained her holy veil and iconic halo, her breasts and pubic bone were enhanced by ornamental hearts, which were attached to her nipples and crotch. Abbey wished to sexualise the mother figure as a matriarchal and religious archetype. Although, she understood that by doing so she was pushing the taboo of religious sensibilities, "there was always a gasp from the audience when the Madonna stripped and started to perform as a go-go dancer".

By demonstrating an axiological switch within the dance from the Blessed Virgin to a sexy nightclub dancer, Abbey is shedding light on the mid $19^{\text {th }}$ century notion of the "hoisting of woman onto a monumental pedestal of virtue" (Dijkstra 1986, 19) to demonstrate "a male fantasy of ultimate power, ultimate control - of having the world crawl at his feet" $(1986,19)$. If we follow Dijkstra's approach towards the "hoisting of woman onto a monumental pedestal of virtue" then Abbey's treatment of the fifth veil perpetuates rather than questions a patriarchal tradition. The Virgin Mary becomes sexualized as she entices the male onlookers to a fever of unbridled ecstasy to coincide with Wilde's notion of religion for the sake of aesthetics. Following Abbey's exploitation of religion through exploring the aesthetics in dance, the proceeding veil retraced the geographical locale of the biblical narrative. Abbey explored the ancient and the exotic as she captured the dancer in full flight in an aerial version while expanding upon the motif of the veil to its greatest extent.

Dressed in Middle Eastern attire, the sixth veil commenced her erotic dance utilising the silks from her dress as Herod removed them one by one. Once the dancer was half naked, she took hold of the long black silk veil that was suspended from the ceiling. Since the colour black is often associated with death, the sixth dancing veil adopted a rather ominous quality as the Dance of the Seven Veils closely approached its dramatic climax. Such a depiction may reference the dark and threatening mood of Iokanaan's prophetic words :

In that day the sun shall become black like sackcloth of hair, and the moon shall become like blood, and the stars of the heaven shall fall upon the earth like unripe figs that fall from the figtree, and the kings of the earth shall be afraid (120).

Herod lay underneath the spiralling dancer as she excelled in a series of sublime aerial feats. While she spun in circles, her legs in 180 degree splits, Herod tirelessly yet unsuccessfully attempted to catch her as he engaged in a voyeuristic power struggle with the suspended silk. Just as Herod is finally about to connect with the sixth veil, she swiftly snatches the black silk she used throughout her aerial performance, which obscurely appears in mauve due to the considerable inundation of red stage lighting, and runs for the wing of the stage. Herod chases after her, but is engulfed in the enormous gust produced by the traveling veil as to create the illusion of a stage curtain, which reveals the seventh and final veil. 
chrysolites, beryls, chrysoprases, rubies, sardonyx, hyacinth and chalcedony stones, crystals, turquoises, amber, fans fashioned from the feathers of parrots, a garment of ostrich feathers, sandals incrusted with glass, mantles and bracelets decked about with carbuncles and with jade. However, the last and most precious gift Herod offered Salomé was "the veil of the Sanctuary" : "I will give thee the mantle of the high priest. I will give thee the veil of the Sanctuary" (154). When Salomé rejects his offer and demands for the final time : "Give me the head of Iokanaan!" (154) Herod is completely defeated and at last utters the decisive words, which finally seal the prophet's fate, "Let her be given what she asks! Of a truth she is her mother's child !" (156). Once the waltz draws to a close, Salomé and Herod suddenly cease dancing as they dramatically grip one another in a tight embrace. Overcome with desire, Herod begins to unravel her dress. Small magnets were attached to the garment so as to make the removal effortless. "As Salomé spun around in circles", Abbey explained, "Herod unpeeled the dress like an orange rind". When asked if the final veil represented Salomé, Abbey responded, "Yes, it does. As soon as it unravels and she falls to the floor, that is her, that is Salomé".

Abbey showcased all the female sexualized archetypes as they were previously presented in the preceding six veils. However, the final veil morphed into Salomé herself in order to delineate her protagonist's evolution and to illustrate the dramatic arc of her elusive character through the progression of a nine-minute dance instrumental. Karl Toepfer's meticulous work entitled The Voice of Rapture: A Symbolist System of Ecstatic Speech in Oscar Wilde's Salomé (1991) suggests : 
That the veils should reveal seven distinct facets of the dancer's fragmented identity is indeed remarkable and certainly a task of immense difficulty for the actress. Wilde does not identify the nature of these distinct facets, yet spectators seem fond of the phrase, dance of the seven veils, without having any clear idea of what either the phrase or the dance attempt to represent" (137).

Although the true "nature" of Wilde's veils is indeed ambiguous and therefore a mystery to all who attempt to elucidate its meaning, Abbey takes up the ambitious task of translating Toepher's notion of "seven distinct facets of the dancer's fragmented identity" in order to offer a fresh insight that challenges the social, cultural and religious conventions of today.

Abbey's original reading of Salomés Dance of the Seven Veils initiates a fluid and intellectually satisfying interaction between performer and spectator to allow him or her to decipher their unique interpretation(s). Through an interchangeable dialogue between choreographer and dancer, Abbey is able to transmit her preference for multiplicity to an audience. Moreover, she offers the spectator the opportunity to construct individual readings through the dancer's performing body. As spectators, we decode the dancer's language to arrive at our own individual receptive interpretation as we engage in the role of co-creator, reader and collaborator.

In a bold and daring reinterpretation of Strauss's Salomé, Abbey used dance as a medium and a language to communicate her unique and desired interpretation of Wilde's enigmatic single-line stage direction, "Salomé dances the dance of the seven veils". Modern dance legend Martha Graham is quoted as saying "Dance is the hidden language of the soul" (Kessel 2006, 9) and it is evident that Abbey does not just speak this implicit language, she sings and shouts its body of words at full voice for all to hear. Through her multi faceted exploration into male and female sexuality, she masterfully demonstrates how the Dance of the Seven Veils exists as an ingenious puzzle reinforcing Wilde's taste for mystery and paradoxes. Moreover, Abbey illustrates the manner in which the infamous dance continues to endure through original adaptations, which in turn can be relevant to our contemporary culture.

\section{BIBLIOGRAPHY}

Cave, Richard Allen. “Staging Salome's Dance in Wilde's Play and Strauss's Opera”. In Refiguring Oscar Wilde's Salome, ed. Michael Y. Bennett, 145-166. Amsterdam \& New York : Rodopi, 2011.

Claid, Emilyn. Yes? No! Maybe : Seductive Ambiguity in Dance. London \& New York : Routledge, 2006.

Dijkstra, Bram. Idols of Perversity : Fantasies of Feminine Evil in Fin-de-Siècle Culture. New York:

Oxford University Press, 1986.

Eco, Umberto. The Open Work. Translated by Anna Cancogni with an Introduction by David Robey. London : Hutchinson Radius, 1989.

Kessel, Kristin. The Library of American Choreographers : Martha Graham. New York : The Rosen Publishing Group, 2006. 
Kuryluk, Ewa. Salome and Judas in the Cave of Sex. Evanston : Northwestern University Press, 1987.

McCallum, Peter. "Fresh Twist Lifts Essay in Desire and Decadence" Sydney Morning Herald October 15, 2012.

Riquelme, J.P. Shalom/Solomon/Salomé: Modernism and Wilde's Aesthetic Politics. The Centennial Review, vol. 39, No. 3 (Fall 1995), pp. 575-610.

Santini, Daria. "That Invisible Dance : Reflections on the 'Dance of the Seven Veils' in Richard Strauss's Salome”. In Dance Research: The Journal of the Society for Dance Research, vol. 29, No. 2 (Winter 2011), pp. 233-245. Edinburgh University Press.

Toepfer, Karl. The Voice of Rapture : A Symbolist System of Estatic Speech in Oscar Wilde's Salomé. New York : Peter Lang, 1991.

Wilde, Oscar. Salomé. Paris : GF Flammarion, 2006.

Kelly Abbey. Interview : November 7, 2015

\section{NOTES}

1. Capitalization is used when referring to the Dance of the Seven Veils. However, when citing Wilde's stage direction lower case will be used.

\section{ABSTRACTS}

The obscure naming of the Dance of the Seven Veils from Oscar Wilde's 1891 symbolist tragedy Salomé embodies the author's ambition for mystery and intrigue. Richard Strauss embraced the ambivalent naming as he created a nine-minute instrumental to invite directors and choreographers to engage in original and creative interpretations. In Opera Australia's 2012 controversial adaptation of Strauss's Salomé, choreographer Kelly Abbey accepted this challenge with full force as she used professional dancers to perform each of the seven veils. By showcasing seven different archetypal images of the sexualized woman as seven different dancing veils, Abbey's inventive and original approach to the infamous dance challenged and remodelled preconceived notions of seduction in Western culture.

L'appellation obscure de Danse des Sept Voiles de la tragédie symboliste d'Oscar Wilde, Salomé (1891), incarne l'ambition de l'auteur pour le mystère et l'intrigue. Richard Strauss a adopté cette dénomination ambivalente en créant un passage de neuf minutes pour lequel les metteurs en scène et les chorégraphes peuvent proposer des interprétations originales et créatives. Dans l'adaptation controversée de Salomé de Strauss par l'Opera Australia en 2012, la chorégraphe Kelly Abbey a relevé ce défi avec panache en utilisant des danseurs professionnels pour interpréter chacun des sept voiles. En présentant sept archétypes de la femme sexualisée sous la forme de sept danseuses différentes, l'approche inventive et originale d'Abbey remet en question et remodèle les notions préconçues de la séduction dans la culture occidentale. 
INDEX

Keywords: opera, dance, theatre, Wilde, Salomé, Strauss

Mots-clés: opéra, danse, théâtre, Wilde, Salomé, Strauss Subjects: Theater

\section{AUTHOR}

GERRARD CARTER

$\mathrm{PhD}$

University of Melbourne

gerrard.CARTER@univ-amu.fr 